\title{
Elements of Sovereign-Debt Default in the MENA Region
}

\author{
Nicholas Bitar ${ }^{1}$ \\ ${ }^{1}$ Faculty of Business Administration and Economics, Notre Dame University, Zouk Mosbeh, Lebanon \\ Correspondence: Nicholas Bitar. E-mail: nicholas@bitarcompany.com
}

Received: October 7, 2020

Accepted: October 28, 2020

Online Published: November 30, 2020

doi:10.5539/ass.v16n12p93

URL: https://doi.org/10.5539/ass.v16n12p93

\begin{abstract}
In the past half-century, the MENA region has witnessed several political uproars, varying between internal instability and conflict to external assaults and disputes. Studies conducted on developing countries have shown that political risk factors have, one way or another, rushed the governments' decision to default on their debt. The purpose of this study is to examine the significance of the determinants of sovereign debt default. The aim here is to find the correct set of independent variables, whose effect is significant and are agreed upon generally in the literature. The empirical study is a panel data that samples 35 years 1984-2018 for all MENA countries. From the political perspective, I find that corruption and cohesion are the factors that stand behind sovereign debt default. From the economic standpoint, inflation and debt to GDP ratio are significant and positively related indicators to sovereign debt defaults. Whereas, trade openness is significant and negatively related. Moreover, the results reveal that GDP growth is insignificant, this finding contradicts the literature of the determinants of sovereign debt.
\end{abstract}

Keywords: sovereign debt, political risk, default, governance, corruption, cohesion, trade openness, inflation rate, and growth

\section{Introduction}

Sovereign debt refers to debt incurred by governments. The phenomenon of developing countries defaulting on their debt is a largely discussed issue in the literature of international economics and finance; several studies have been conducted to determine the major factors behind these defaults and just how significant they are.

Sovereign debt default can occur due to wars or civil conflicts that negatively affect a nation's productivity. It can be triggered by the devaluation of local currency as well. In the latter case default occurs whenever a large part of the debt is allocated in foreign currency.

In the MENA countries; the issue largely goes back to domestic factors. Default is usually a result of poor financial management, where governments' expenditures far exceed revenues. The problem is that, in the MENA countries huge budgets are spent on unprofitable projects, or squandered in military and warfare expenditure or even stolen by government officials.

According to the literature of sovereign defaults, political factors are important determinants. Citron and Nickelsburg (1987) find that political instability is a significant determinant that affects sovereign defaults. Balkan (1992) in his two dimensions of borrowing political environment; democracy and political instability index. He finds these factors statistically significant in explaining default probabilities. Kohlscheen (2003) concludes that presidential systems experience a higher probability of default than parliamentary democracies. His insight is that parliamentary systems include a higher number of veto players.

Initial defaults cause governments to accumulate more debt, and end up indebting billions of dollars to developed countries, consequently, creditor countries would gain more political power and alter international affairs to work for their benefit. That is how sovereign debt has made the world in the shape that it is now, a relationship explicitly discussed by Kobrin (1977). Therefore, the governments of these developing countries should be more aware of their dire situation, and try to neutralize the effects of the elements of debt default as much as possible, if they intend to develop. Studies like this one can be used as policy implications for economists of these countries, with each determinant given its level of impact and what exact kind of default it alters.

This paper aims to empirically analyze the factors that are behind sovereign defaults in the MENA region. It is 
the only paper that includes all countries in the region, 19 MENA countries (Palestine is excluded due to lack of data) with the most possible years of observations 35 years 1984-2018 (due to data limitations in reference to ICRG). Furthermore, this paper includes the widest range of economic and political factors that are considered in the literature. The next section presents the literature over sovereign debt default, both economic and political. Section 3 introduces the methodology that is used in this paper. Section 4 presents the empirical results. Section 5 concludes.

\section{Literature Review}

Studies that attempted to find and test the significance of sovereign defaults were numerous; and several major contributions were made over the years. In the early eighties and at the peak of the worldwide debt crisis, the main focus of most research was on the economic factors behind default. Feder et al. (1981), Cline (1984), and Morgan (1986) related sovereign debt to issues of central government budgeting, trade, GDP and, central banking. However, these studies didn't take into account the impact of other political and social factors that have proven to be determinants of defaults. This was because it is hard to agree on a correct measure of political risk, and the relationship between political economy and debt structure was never fully understood nor did it get that much attention from researchers until the light was shed on political risk first by Korbin (1979), who showed that political risk does in fact, affect the decision making process by managers in international firms, and implicated an extension to the macro level.

Following this realization political risk variables were added to empirical models, the inaugural paper of these studies was by Citron and Nickelsburg (1987), who introduced to their model a political index measured by changes of government and despite that this variable was proven to be significant, it's unsuitable for this model, since the sample countries used, are mostly governed by dictatorships and hence witnessed few changes of government in that period. Also, government changes can come in several forms; revolutions, elections, outside, or even voluntary resignation, therefore to imply that changes of government are an appropriate indicator of political risk would be an extreme generalization. Balkan (1992) presented a different method for measuring political risk, in his research, he measured political unsettledness by then level of democracy and showed that democratic governments had a lower probability of rescheduling their debts. But just like its predecessors, the proxy of political instability used is unclear and abstract and was a discrete measure making it hard to perfectly analyze the link between political risk and sovereign debt default. Zeaiter and El-Khalil (2016) implemented the political risk index formed by the International Country Risk Guide (ICRG), they studied sovereign defaults in the MENA region over the period 1970 to 2010 they found out that; countries in the MENA region with a high level of corruption and democratic accountability risks (risk rating as provided by the ICRG group) are expected to accumulate debt arrears, making them more likely to default.

Apart from the political variables, other economic determinants have also seen some development in the literature; Lausev et al. (2011) made a major contribution in that matter, where they found that the probability of debt rescheduling can be lowered by reducing government expenditure, attracting foreign direct investment, increasing export revenues, and keeping a good repayment record. The focus of this research was on eastern European countries, but the variables mentioned have also proved to be highly significant in developing countries from other regions as well. Hilscher and Nosbusch (2010) investigate the effects of macroeconomic fundamentals on market sovereign credit spreads. They found that the volatility of terms of trade has a statistically significant effect on sovereign credit. Manasse and Roubini (2009) found that the default is high in case of high external debt (over 50\% of GDP). Yet, public debt to GDP is a less useful warning indicator - unlike external debt. Sturzenegger and Zettelmeyer (2006) researched the key sovereign default clusters for the last 200 years. They observed that external factors are crucial, factors such as; deterioration of terms of trade, a recession in countries that provide capital, an increase in international borrowing costs, and crises in major countries that spread across trade and financial markets. Similarly, Reinhart et al. (2016) showed that the collapse of commodity markets and international capital flows are strong predictors of sovereign debt default. An external debt default by many nations since 1815 occurred where a sudden stop in global capital flows struck together with a collapse in global commodity prices. Bandiera et al. (2011) using panel data for 46 FCAS/MENA countries for the 1980-2004 period the authors concluded a negative relationship between sovereign debt default and GDP growth, trade openness, effective interest rate, and current account to percentage reserve. Yet, positively related to the inflation rate and external debt to reserves. Tomz and Wright (2007) collected data on 106 countries, 1820-2004 from FCAS/MENA. The authors found a negative relationship between GDP and default on sovereign debts. They believed that default is optimal whenever there is a significant reduction in the government budget, nation's export, or output in the indebted nation's tradable sector. Pescatori and Sy (2007) they used several data samples list, from FCAS/MENA countries 1975-2002. The authors realized a negative 
relationship between sovereign debt default, GDP growth, and trade openness. A direct relationship with inflation and debt to GDP ratio. Kraay and Nehru (2006) their study included data on 94 crisis episodes in low-income FCAS/MENA countries, 1970-2001. Their key findings were a positive relationship on debt to export ratio, and a negative relationship to GDP growth, and depreciation. Yet, inflation, GDP per capita, and term of trade growth showed an ambiguous effect. Kruger and Messmacher (2004) the authors used data on 42 FCAS/MENA countries, 1970-2001. They noticed that sovereign debt default is related positively to debt to exports, long-term debt services to reserves, and GDP. And negatively to current account deficit to GDP, debt to export, and export growth. Catão and Sutton (2002) their study included data on 25 emerging FCAS/MENA markets, 1970-2001. They separated aggregate volatility into external and domestic policy components. They found a positive relationship with the term of trade, exchange rate, external debt service to export, and volatility of fiscal policy. Furthermore, a negative relationship with the real GDP growth, and foreign exchange reserve to debt ratio. Ghulam and Derber (2018) used panel data over 70 countries to study major sovereign defaults over the period 1970- 2010. Their key findings were; Political instability, rise in inflation, interest rates, current account deficit, and increase in debt/GDP ratio increase the probability of default. Whereas, improvement in GDP per capita, and export growth, reduces the probability of default. Catao and Ferretti (2014) used the crisis model to examine the determinants of external crises while focusing on foreign liabilities and their composition. The crisis model begins by selecting the appropriate model to be used. During that phase, they used the so-called the ROC curve to enable them to choose the appropriate model. The sample consists of 72 countries spanning from 19702011. They concluded that net foreign liabilities to GDP is a significant crisis indicator. Also, the current account is a powerful predictor, foreign exchange reserves reduce the possibility of crisis. Thus, deterioration mostly reflects a worsening net external debt to GDP position.

\section{Data and Methodology}

Throughout the years, many significant determinants of default were introduced, and in some cases, it seemed hard to decide what to use in the model. The decision of what variables to choose is based on what is common in the literature. According to Zeaiter and El-Khalil (2016) poor countries suffer from poor investment decisions and excessive government spending, a variable measuring credit to the public sector as a percentage of GDP is included, as the government borrows more domestically, its accrued debt level increases, eventually concluding a positive relationship with the sovereign debt default. Within the same context of a national budget, Kruger and Messmacher (2004) concluded an inverse relation with current account balance, as more money is induced, the government's financial position is improved allowing to better service its debt, and hence a negative coefficient is expected. As a country improves its trade balance it gains an advantage in international finance and thus has a better debt repaying schedule. Trade openness is another factor that affects the sovereign debt default. According to Bandiera et al. (2011) and Pescatori and Sy (2007) trade openness is inversely related to sovereign debt default. Trade openness or freedom in trade would improve the external debt positions of underdeveloped countries. In the sense that, free trade improves national production and profit. Consequently, improving the national trade position. GDP growth is a common determinant for sovereign debt, as in Kraay and Nehru (2006) and Bandiera et al. (2011), they concluded a negative relationship between GDP growth and sovereign debt defaults. GDP growth simply makes the nation wealthier. Hence, external debt settlement could be paid easily. Inflation and interest rate are surely determinants of sovereign debt. According to Ghulam and Derber (2018), a high inflation rate entails high-interest rate or vice versa. High inflation will devaluate the local currency. That would certainly make the external debt burden more difficult to settle while local currency devaluates against external debt. Finally, I add political risk factors according to the International Country Risk Guide (ICRG) for political risk rating by the PRS Group INC to better explain sovereign debt default.

In this section, we follow Bitar et al. (2020) methodology. We use panel OLS regression form for all MENA countries for the years 1984-2018. Moreover, I merge the 12 risk factors in lessor subgroups by applying factor analysis to avoid the multicollinearity problem.

The political risk rating that is provided by the International Country Risk Guide (ICRG) by the PRS Group INC. includes 12 categories. Each category has a weight of either 6 points or 12 points. Where high scores imply low risk and low scores (a score of zero represents the highest possible score) imply high risk. The 12 risk categories and weights are defined and weighed as follows; Risk categories that weigh 12 points are Government Stability with three components: government unity, legislative strength, and popular support, it reflects the government's ability to carry out its declared programs. Socio-economic Conditions with 3 subcomponents: consumer confidence, unemployment, and poverty. Investment Profile also with 3 components: contract viability/expropriation, profits repatriation, and payment delays. It measures factors affecting the risk to investment that are not included in political, economic, and financial risk components. Internal Conflict also 
includes three subcomponents: civil war, threat, terrorism/political violence, and civil disorder assessing political violence and its impact on governance. Categories with 6 points include: External Conflict measures the risk to governments from foreign actions. Subcategories are war, cross-border conflict, and foreign pressures. Corruption, the most common is financial corruption in the form of bribes, exchange controls, tax assessments, or police protection. Military in Politics measures the independency of military involvement in political matters. More involved means more distortion of the government policy or threat of a military take-over. Religious Tensions, when religious groups aim to dominate a society. Such groups seek to replace civil law with religious ones. Law and Order include two categories: The law element measures the fairness and strength of the legal system. The order element assesses the popular observance of the law. Ethnic Tensions, is the tension attributable to nationality racial or language divisions. Democratic Accountability measures the responsiveness of the government to its public. Finally, with only 4 points Bureaucracy Quality is the quality and strength of the government's institutions.

Table 1 presents the summary of the 665 observations for political risk factors with mean, standard deviation, minimum, and maximum. Data represents annual data from 1984-2018. The means for all indicators vary between a low score higher risk and a middle score moderate risk. The table below shows that in the MENA region Bureaucracy Quality, Corruption, Democratic Accountability, Socioeconomic Conditions, and Government Stability is remarkably low. That implies that the MENA region is suffering the most from corruption and governance. Whereas, all other indicators do have moderate risk.

Table 1. Descriptive analysis of the 12 political risk indicators from 1984-2018 for 19 countries (665 observations)

\begin{tabular}{|c|c|c|c|c|c|}
\hline & Obs & Mean & SD & Min & Max \\
\hline Bureaucracy Quality (BQ) & 665 & 1.8981 & .77417 & 0 & 4 \\
\hline Corruption (C) & 665 & 2.5257 & .92617 & .5 & 5 \\
\hline Democratic Accountability (DA) & 665 & 2.7511 & 1.48597 & 0 & 6.5 \\
\hline Ethnic Tensions (ET) & 665 & 3.8045 & 1.45516 & 0 & 6 \\
\hline External Conflict (EC) & 665 & 8.2076 & 2.66401 & 0 & 12 \\
\hline Government Stability (GS) & 665 & 5.6195 & 1.98797 & .5 & 12 \\
\hline Internal Conflict (IC) & 665 & 7.8212 & 2.64875 & 0 & 12 \\
\hline Investment Profile (IF) & 665 & 7.1768 & 2.27764 & 1.08 & 11.5 \\
\hline Law \& Order (LO) & 665 & 3.7253 & 1.348 & 1 & 8 \\
\hline Military in Politics (MP) & 665 & 3.2945 & 1.46068 & 0 & 5.5 \\
\hline Religious Tensions (RP) & 665 & 3.2281 & 1.23068 & 0 & 5.5 \\
\hline Socioeconomic Conditions (SC) & 665 & 5.6195 & 1.98797 & .5 & 11 \\
\hline
\end{tabular}

To avoid multicollinearity, the first step is to merge the 12 political risk factors into smaller categories. That sounds reasonable since some of the political risk factors are highly correlated by nature. For instance, Ethnic Tensions, Government Stability, Internal Conflict, and Law and Order, they are all related. Whenever you do have ethnic tensions in any nation that might create internal conflicts, internal conflicts could affect government stability. Consequently, the law and order will be interrupted in the nation. Likely, External Conflicts, Government Stability, Investment Profile, and Internal Conflict are as well correlated. Whenever a nation is at war with another nation, that might weaken the government, and that could affect the investment inside the nation, which could end up in internal conflicts. In that case, Lebanon is a good example, recently, Lebanon is in conflict with the US. The conflict caused a financial sanction by the US on Lebanon. Hence, the Lebanese government defaulted on its public debt, the industrial sector collapsed as interest rate soared, the financial system collapsed until people went to the streets rioting against one another. Hence, running empirical work while we do have a high correlation among the risk factors will certainly yield biased results. To settle the multicollinearity problem, the best way to manipulate the 12 risk factors, is to run Principal Component Factor Analysis. Factor Analysis will merge (load) all components that do have a high correlation with one another. Consequently, I am downsizing the risk components into lesser quantity.

In Principal Component Factor Analysis the scree plot in Figure 1 is used to decide among the optimal quantity of variable that needs to be used for the risk factors. According to Factor Analysis, all risk variables will continuously load onto other variables until all variables will get an Eigenvalue greater than 1 . In that case Figure 1 shows that the number of independent risk factors must be downsized into three. (After the third factor the Eigenvalues will drop below 1). That implies 3 is the optimal quantity of independent variables that risk 
factors must be merged into while eliminating multicollinearity.

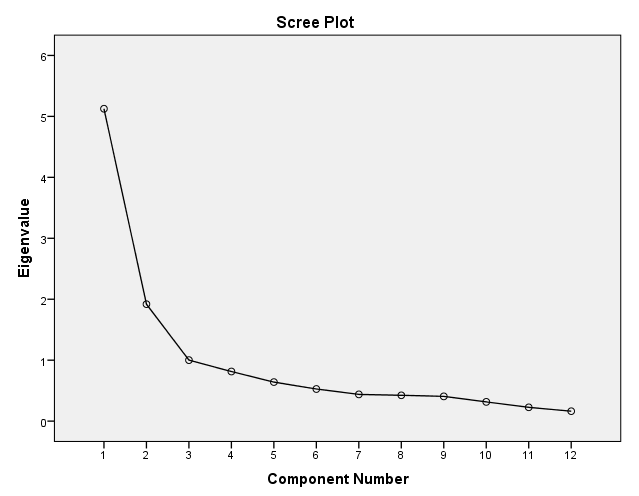

Figure 1. Scree plot

In Table 2 the political risk indicators are distributed over three factors (fac 1 through fac 3). By inspecting the factor loadings, (as the value of the factor loading approaches to unity, the variable will likely load on that factor) each variable will load on the factor with the highest score. Table 3 summarizes the placement of all risk indicators among the three-factor groups. Government stability, socioeconomic conditions, investment profile, military in politics, external conflicts, and law and order are loaded on factor 1 . The best likely description of factor 1 is as in Bitar et al (2020) governance. Since the factor loading includes the same factors that directly relate to controlling. As a matter of fact, the high rating in governance implies government stability, law and order, socioeconomic conditions, and military in politics are all related to governance. Government stability is translated into a reliable government. Hence, if the government system is reliable and organized, less resistance will be among people. That leads to law and order, the military does not interfere in politics, and finally a favorable socio-economic conditions. Concerning investment profile, it might not be related to governance yet, it is highly correlated. In the sense that whenever governance is highly rated, a stable government is foreseen, and that leads to improvement in investment profile. Similarly, external conflicts are likely correlated to governance, since lack of control might end up in conflicts that enables foreign nations to interfere in the system. One example could be Lebanon, due to lack of governance recently, policymakers started seeking foreign support. Today the nation is suffering from external conflicts with several nations because some political parties do support foreign interventions while others do not. Factor 2 loads only one constituent variable, corruption. Hence, it will be called corruption. The final factor loads, ethnic tensions, religious tensions, internal conflicts, bureaucratic quality, and democratic accountability. Most of the constituents of factor 3 deals with unity. So, factor 3 is summarized similarly to Bitar et al (2020) by cohesion. Certainly, all elements are directly related to cohesion. In other words, whenever unity prevails, a nation should score high on ethnic tensions, similarly for religious tensions, with no tension visible between citizens internal conflicts are likely to be minimal. Moreover, whenever unity prevails, bureaucratic quality, and democratic accountability should overcome.

Table 2. Pattern matrix

\begin{tabular}{cccc}
\hline & \multicolumn{2}{c}{ Rotated Component Matrix $^{\mathrm{a}}$} & \\
\hline & & Component & Fac 3 \\
\cline { 2 - 4 } & Fac 1 & Fac 2 & -.270 \\
\hline Government Stability GS & .770 & -.113 & .236 \\
Socioeconomic Conditions SC & .702 & .151 & -.211 \\
Investment Profile IF & .797 & .291 & .271 \\
Internal Conflict IC & .821 & -.261 & .141 \\
External Conflict EC & .743 & -.070 & .871 \\
Corruption C & .035 & .158 & .455 \\
Military in Politics MP & .627 & .010 & .139 \\
Religion in Politics RP & .467 & -.560 & .302 \\
Law and Order LO & .775 & .060 & .082 \\
Ethnic Tensions ET & .719 & -.349 & .164 \\
\hline
\end{tabular}




\begin{tabular}{cccc}
\hline Bureaucracy Quality BQ & .415 & .632 & .464 \\
\hline
\end{tabular}

Extraction Method: Principal Component Analysis.

Rotation Method: Varimax with Kaiser Normalization.

a. Rotation converged in 10 iterations.

Table 3 categorizes the 12 factors with their component variables based on the Principal Components Factor Analysis results.

Table 3. Factor names and their component variables

\begin{tabular}{ccc}
\hline Factor 1: Governance & Factor 2: Corruption & Factor 3: Cohesion \\
\hline Government Stability & Corruption & Democratic Accountability \\
Socioeconomic Conditions & & Ethnic Tensions \\
Investment Profile & & Religious Tensions \\
External Conflict & Internal Conflicts \\
Law and Order & Bureaucracy Quality \\
Military in Politics & \\
\hline
\end{tabular}

The next step is introducing the empirical model. The dependent variable is the amount of credit a nation is borrowing from the IMF as a lender of last resort. The independent variables include the macroeconomic variables that are found significant according to the preceding literature together with the 3 political risk factors derived earlier. The regression model follows the form;

$$
I M F=\beta 0_{+} \beta 1 F A C 1+\beta 2 F A C 2+\beta 3 F A C 3+\beta 4 O P E N+\beta 5 I N F L+\beta 6 D B T G D P+\varepsilon .
$$

FAC1: Pooled Political risk factors that deal with governance indexed by ICRG pooled by factor analysis technique.

FAC2: Pooled Political risk factors that deal with corruption indexed by ICRG pooled by factor analysis technique.

FAC3: Pooled Political risk factors that deal with cohesion indexed by ICRG pooled by factor analysis technique.

OPEN: Trade openness, derived as (IMPORTS+EXPORTS/GDP), and measured in nominal value.

INFL: Inflation rate, derived as the annual Consumer Price Index percentage change $\left(\mathrm{CPI}_{2}-\mathrm{CPI}_{1}\right) / \mathrm{CPI}_{1}$,

DBTGDP: Debt to GDP ratio, derived as external debt stock public and publicly guaranteed divided by nominal GDP calculated as (External public debt)/GDP 1

\section{E: Error term}

The panel data regressions use 19 MENA region countries from 1984-2018 with a sum of 665 observations. Risk factors observations are derived from Political Risk Services group (PRS) and International Country Risk Guide (ICRG). Whereas, imports, exports, GDP, CPI, and external debt are derived by the International Monetary Fund (IMF), and World Economic Output Database (WEO). It is worth mentioning that some independent variables derived and proven significant by the literature are omitted for having very low significance levels in order to make our model fit and consistent as possible. Some worthwhile variables that are proven insignificant are, growth, per capita growth, current account balance, and exchange rate. The interest rate was eliminated simply because it is highly correlated to the inflation rate.

Table 4. Multivariate linear regression analysis for the predictors of IMF borrowing

\begin{tabular}{|c|c|c|c|c|}
\hline Variables & $\overline{\mathbf{R}^{2}}$ & $\mathbf{R}^{2}$ adjusted & Unstandardized Beta & P value \\
\hline Constant & & & 870809409 & 0.000 \\
\hline FAC 1 GOVERNANCE & & & 350538028 & 0.058 \\
\hline FAC 2 CORRUPTION & & & -142406245 & 0.000 \\
\hline FAC 3 COHESION & & & -186969630 & 0.013 \\
\hline OPEN & 0.39 & 0.37 & -5125147 & 0.014 \\
\hline INFL & & & 9335978 & 0.000 \\
\hline DBT/GDP & & & 364997738 & 0.017 \\
\hline
\end{tabular}




\section{Results}

The results of the test are displayed in Table 4, as mentioned earlier, the current account, growth, and exchange rate were removed. While current account balance and growth do show insignificant results. Whereas exchange rate reveals an opposite sign and insignificant result. Factor 1 that deals with governance are insignificant and yet reveals a wrong sign. Perhaps because governance is not the best indicator for sovereign debt default. Alternatively, both corruption and cohesion are significant and include a negative sign. According to the International Country Risk Guide (ICRG), the political risk rating by the PRS Group INC. scores 0 for the lowest rating (high risk) and 12 for the highest rating (lowest risk, while in some cases 6 is the lowest risk score instead). Having said so, countries that do have lots of corruption and internal conflicts (none-cohesion) do score lower on the ICRG rating. Therefore, an inverse relation implies that a higher level of IMF borrowing is explained by lower score ratings, in accordance with the findings of the OLS regression presented in Table 4. So the model confirms that corruption, ethnic, religious and, internal tensions are a major element that stands behind sovereign debt default for MENA countries. Concerning economic variables, inflation has a positive and significant sign. That implies high inflation will positively affect the IMF borrowing. Hence, confirming what is concluded in the literature by many economists. In other words, higher inflation creates unstable economic conditions and uncertainties that might affect the nation's exchange rate, increase trade deficit, and government budget deficit. Consequently, if the nation at hand is in debt to the rest of the world, default on the debt becomes a possibility and that will push the nation towards the lender of the last resort, which in this case is to borrow from the IMF. The debt to GDP ratio is significant and yet confirms the sign determined by the literature. The debt to GDP ratio does have a positive sign. That implies, as debt increases then debt to GDP ratio increases. Hence, highly leveraged nations or governments will not be able to borrow more from the public nor from other nations. Certainly, other nations will be reluctant to increase the debt to highly leveraged nations since more loans mean more default risk. Today Lebanon is the best example, Lebanon is a nation with high debt to GDP ratio (around $180 \%$ of GDP). In the year 2019 the nation defaulted on paying its external debts and debt interest. The government of Lebanon today is struggling for additional funding from the IMF, after failing to convince the Europeans (Cedars I) to increase their lending. Finally, trade openness is significant and negative. That implies, with more trade openness perhaps a nation will benefit from trade and improves its economy and balance of payment position. Hence, reducing the IMF borrowing.

\section{Conclusions}

This study tries to determine the factors that explain the political and economic reasons behind governments' foreign debt defaults. By studying all countries of the MENA region while using the 12 political risk factors provided by the ICRG, then downsizing them into three groups to avoid muticollinearity, and including economic factors that are realized by the literature, I run a panel data regression and find the following facts; from the political perspective, basic reasons behind sovereign debt defaults are corruption and cohesion. Religious and ethnic tension reduces the bureaucratic quality and that creates internal conflicts between religious groups. This would open the door for corruption. Consequently, corruption and internal conflicts can affect the wellbeing of the macroeconomy especially weakening the government sector. At this point, the government must borrow extensively to cover the additional expenses that are generated from corruption and internal conflicts. From the economic perspective, the factors that are proven significant and positively related to sovereign debt are debt/GDP ratio and inflation. Whereas, trade openness is inversely related. Surprisingly, the results show that GDP growth is insignificant. Hence, this finding contradicts the literature. Perhaps this finding is exceptional to the MENA region. Therefore, it may be useful if the same study is conducted globally. If those determinants can work across the whole world, then elements of sovereign debt default can be concluded worldwide.

\section{References}

Balkan E. (1992). Political Instability, Country Risk and Probability of Default. Applied Economics, 24(9), 999-1008. https://doi.org/10.1080/00036849200000077

Bitar, N. (2020). The Aftermath of the Tariff War on China. Asian Social Science, 16(2), 22-30. https://doi.org/10.5539/ass.v16n1p22

Catão, L. A., \& Milesi-Ferretti, G. M. (2014). External liabilities and crises. Journal of International Economics, 94(1), 18-32. https://doi.org/10.1016/j.jinteco.2014.05.003

Catão, L., \& Kapur, S. (2006). Volatility and the debt-intolerance paradox. IMF Staff Papers, 53(2), 195-218. https://doi.org/10.2307/30036011

Citron, J., \& Nickelsburg, G. (1987). Country Risk and Political Instability. Journal of Development Economics, 
25, 385-392. https://doi.org/10.1016/0304-3878(87)90092-7

Cline, W. (1984). International Debt: Systematic Risk and Policy Response. Journal of Development Economics, 22(2), 396-399.

Feder, G., Richard, E., \& Ross, K. (1981). Projecting Debt Servicing Capacity Applying Logit Analysis. Journal of Development Economics, 4, 25-38.

Ghulam, Y., \& Derber, J. (2018). Determinantbof Sovereign defaults. The Quarterly Review of Economics and Finance, 69, 43-55. https://doi.org/10.1016/j.qref.2017.12.003

Hatchondo, J., Martinez, L., \& Sapriza, H. (2007). The Economics of Sovereign Defaults. Economic Quarterly, 92(2), 163-187.

Hilscher, J., \& Nosbusch, Y. (2010). Determinants of Sovereign Risk: Macroeconomic Fundamentals and the Pricing of Sovereign Debt. Review of Finance, 14(2), 235-262. https://doi.org/10.1093/rof/rfq005

Kobrin, S. J. (1979). Political Risk: A Review and Reconsideration. Journal of International Business Studies, 10, 67-80. https://doi.org/10.1057/palgrave.jibs.8490631

Lausev, J., Stojanovic, A., \& Todarovic, N. (2011). Determinants of Debt Rescheduling in Eastern European Countries. Economic Annals, 188. https://doi.org/10.2298/EKA1188007L

Morgan, J. B. (1986). A New Look at Debt Rescheduling Indicators and Models. Journal of International Business Studies, 17, 37-54. https://doi.org/10.1016/1044-0283(91)90003-P

Kohlscheen, E. (2007). Why are there serial defaulters? Evidence from constitutions. The Journal of Law and Economics, 50(4), 713-730. https://doi.org/10.1086/519814

Kraay, A., \& Nehru, V. (2006). When is External Debt Sustainable? The World Bank Economic Review, 20(3), 341-365. https://doi.org/10.1093/wber/lhl006

Kruger, M., \& Messmarcher, M. (2004). Sovereign Debt Defaults and Financing Needs. IMF Working Paper.

Manasse, P., \& Roubini, N. (2009). "Rules of thumb" for sovereign debt crises. Journal of International Economics, 78(2), 192-205. https://doi.org/10.1016/j.jinteco.2008.12.002

Pescatori, A., \& Sy, A. N. (2007). Are debt crises adequately defined? IMF Staff Papers, 54(2), $306-337$. https://doi.org/10.1057/palgrave.imfsp.9450010

Reinhart, C. M., Reinhart, V., \& Trebesch, C. (2016). Global cycles: Capital flows, commodities, and sovereign defaults, 1815-2015. American Economic Review, 106(5), 574-80. https://doi.org/10.1257/aer.p20161014

Sturzenegger, F., \& Zettelmeyer, J. (2006). Debt defaults and lessons from a decade of crises. MIT press.

Zeaiter, H., \& Khalil, R. (2015). Extreme Bound of Sovereign Defaults: Evidence from the MENA Region. International Review of Economics \& Finance, 41. https://doi.org/10.1016/j.iref.2015.10.003

\section{Copyrights}

Copyright for this article is retained by the author(s), with first publication rights granted to the journal.

This is an open-access article distributed under the terms and conditions of the Creative Commons Attribution license (http://creativecommons.org/licenses/by/4.0/). 